\title{
The Style of the Present: Karel Teige on Constructivism and Poetism
}

In 1929, Karel Teige - the leading theoretical voice of the Czech interwar avant-garde and a prolific critic of modernist literature, art, and architecture - published a review of Le Corbusier's project for a world cultural center called the Mundaneum. Le Corbusier had every reason to expect accolades: Teige had been a tremendous admirer and had been enormously influenced by Le Corbusier ever since their first meeting in Paris in mid-1922. But surprisingly, Teige criticized the Mundaneum project as representing, in effect, a design for an avant-garde cathedral. Teige stated that "in its obvious historicism and academicism, the Mundaneum project shows the present non-viability of architecture thought of as art."'

That in the late 1920s Teige should accuse the doyen of avant-garde architecture of practicing "obvious historicism" is striking, and Le Corbusier was clearly taken aback by the criticism. ${ }^{2}$ Indeed Le Corbusier could only interpret this charge as the implementation of utilitarian "police measures" against his own "quest for harmony" and aesthetic efficacy. ${ }^{3}$ Architectural historians, invoking less judgmental yet analogous categories, have represented the Mundaneum polemic as exposing a major rift within architectural modernism: George Baird, for example, has situated Teige's "all-encompassing 'instrumentalization"” within a general "shift of tone ... toward a radically matter-of-fact and materialist conception of architecture ...," and Kenneth Frampton has written of the opposition between Le Corbusier's "humanist" modernism and the "utilitarian" radicalism of figures such as Teige and Hannes Meyer. ${ }^{4}$

What such accounts overlook, however, is how Teige's apparently strict and ungenerous evaluation of the Mundaneum was anchored in extravagant aesthetic claims Teige made elsewhere for Constructivism as the architectural "style of the present." The radical antihistoricism so prominent in Teige's Mundaneum polemic was thus driven by equally radical claims about the historical status of Constructiv-

\footnotetext{
ABSTRAG T In this essay, the Czech avant-gardist Karel Teige's dual program of Constructivism/Poetism is interrogated in the context of his own claim that architectural historicism was degraded by the rupture into a duality of structure and ornament. This inability to escape the terms of his own critique is shown to be the result of Teige's articulation of avant-garde culture as the embodiment of the historical identity or style of the present. / Representations 88. Fall 2004 (C) 2005 The Regents of the University of California. is S N 0734-6018, electronic is S N 1533-855X, pages 102-24. All rights reserved. Direct requests for permission to photocopy or reproduce article content to the University of California Press at www.ucpress.edu/journals/rights.htm.
} 
ism. That Teige's merciless functionalism could be couched in such terms reveals a logic of historical nostalgia inhabiting even the most bracing rejection of historical precedent.

Teige's copious writings in fields other than architecture, as well as the trajectory of his thought over the course of the 1920 s, show a thinker more complex than the allegedly puritanical functionalist of the Mundaneum debate. For most of the decade Teige conceived Constructivism as only one "pole" of avant-garde culture, coexisting with a complementary principle he termed Poetism. Poetism — which during the twenties served as a rallying cry for Devétsil, the most significant grouping of writers, artists, and architects of the Czech 1920s avant-garde - proclaimed and celebrated the ludic spontaneity of modern life, drawing inspiration from mass cultural forms such as film, jazz, and circuses, and even from activities such as tourism and athletics. ${ }^{5}$ Whereas Constructivism had emerged out of the architectural critique of ornament (Teige named Gustave Eiffel, the Chicago School, and especially Adolf Loos as major forebears), Poetism invoked a critique of the traditional "descriptive" literary and visual image, a critique that Teige identified at times with mass cultural innovators such as Charlie Chaplin and at times with literary modernists such as Charles Baudelaire, Stéphane Mallarmé, and Guillaume Apollinaire. ${ }^{6}$ Teige envisioned this dualism as the expression of a dialectical unity within a series of oppositions: rationality and irrationality, purposeful action and antiinstrumental Wohlgefallen, scientific functionalism and pure lyricism, and everyday life and aesthetic elation. The dualism was thus intended to reconcile fundamental yet conflicting positions within avant-gardist discourse: radical productivism (opposed to any understanding of aesthetics as independent of material production) with a liberatory aesthetic celebrating the release of pure poetic form. Like few other thinkers of the time, Teige directly confronted the daunting task of articulating an overarching theoretical framework for the disparate facets of 1920s avantgarde culture. ${ }^{7}$

But this dual scheme entangled Teige in a series of logical contradictions. The contradiction that was most crucial here was not, as one might expect, any of the particular conceptual tensions between Constructivism and Poetism. Those tensions functioned more as the fuel for the dialectical engine: their combustibility was what kept Teige's system moving forward. What ultimately revealed the route as a dead end, however, was the very structure of the dualism itself. For Teige's theory of Constructivism centered on a critique of architectural historicism that identified a conceptual rift marring the integrity of historicist architecture: a conceptual rift that Teige (following Loos and others) felt took material form in the application of decorative layers of historical ornamentation on top of a functional structure that should have been deemed complete in itself. Given the importance of this critique of a "structure/ornament dualism" in Teige's writings of the twenties, the appearance of a parallel dualism in the Constructivism/Poetism structure is striking indeed. Teige himself exerted considerable effort to avoid having Poetism appear as 
a decorative addendum to the severe teachings of Constructivism: effort that not only involved ever more laborious formulation of the dialectical unity of the poles but also drove him to articulate his Constructivism in ever more radical tones (as Le Corbusier would experience firsthand). These efforts, however, traced a vicious circle: the more radically Teige pushed the limits of Constructivism, the more insistently Poetism appeared as its ultimate promise - while at the same time the more difficult it became to justify this dual structure given the standards of Constructivism. $^{8}$

Thus, while the project of delineating a consistent theoretical framework for the avant-garde out of obviously incompatible principles perhaps displayed open utopianism, Teige's utopianism was not simply the product of a theoretician's greed. Rather, this utopian aim of reconciling the irreconcilable can be shown to issue from precisely the most earthbound element of Teige's thought: his hard-headed functionalism. The prime interest of Teige's dualist program in the twenties, therefore, lies neither in his formulations of Constructivism or Poetism taken independently, nor even in his juxtaposition or attempted dialectical synthesis of the two poles. Rather, the dualism is significant because Teige unwittingly betrays Constructivism's inability to exist without Poetism. Poetism, the apparent opposite of Constructivism, was actually its inevitable logical consequence and would have emerged in shadowy outline even if it had not been explicitly articulated. The utopianism in Teige's dualism was due to neither naive exuberance nor willful positing of a unity of opposites, but was rather the mark of theoretical consistency. The very purity of Teige's Constructivism summoned its radical antithesis.

The genealogy of Teige's functionalism reveals at the center of this dualist dilemma the very term that was supposed to guarantee Constructivism's rigorous consistency: the notion of style itself. Only shortly before Teige's 1922 meeting with Le Corbusier - which together with Soviet influences led to Teige's articulation in late 1922 of a Constructivist program squarely within the mainstream of the international avant-garde at that time - Teige had been floundering in attempts to redefine and resuscitate the rather ponderous program of "proletarian art," which he had enthusiastically adopted in 1921. The slogan of proletarian art posited the nostalgic ideal of a soon-to-emerge "Socialist Gothic" that would end the perceived aesthetic "interregnum" by creating the stylistic paradigm of a modern folk art for the proletariat. ${ }^{9}$ Within a few months Teige had completely abandoned such rhetoric in favor of celebration of technological media such as cinema and photography, declaring the primacy of the machine for contemporary cultural production. ${ }^{10}$

Teige's adoption of Constructivism thus evolved from an early nostalgic longing for a new historical style that would give the present a standing equivalent to the great historical styles and to the Gothic above all. But the promise of Constructivism to create such historical standing quickly became predicated on its radical rejection not only of all traces of historical decorative systems but also of the very gesture of measuring oneself against the past. The ease of this inversion from 
millenarian expectations of renewal to confident optimism in the new suggests that the boundary separating historical nostalgia from militant hostility to past cultural forms is permeable. Teige shifted smoothly from a perception of the present as existing within a historical vacuum, with the consequent attempt to fill this vacuum by navigating some sort of reinsertion into the historical flux, to the perception of the present as being mired in a surfeit of historical detritus, calling forth the attempt to eliminate this surfeit through a radical clearing of the tables and a new instauration. The dualist dilemma - the insistence with which Poetism presented itself as the culminating product of Constructivism's new instauration - thus represents the trace of this origin in historical nostalgia. Close examination of the logic behind this shift is instructive, for Teige's dilemma is not simply the record of an error: it reveals and replays a paradox fundamental to the avant-garde thesis of a radical rejection of the past.

\section{From Socialist Gothic to the Style of the Present}

The claim that socialist revolution would create the conditions for the emergence of a new and all-encompassing artistic style - often referred to as a "Socialist Gothic" - was a common element of the rhetoric of proletarian art. ${ }^{11}$ In his earliest writings Teige used this idealized image to describe an art that would stand in some sort of immediate relation and be spontaneously comprehensible to the masses rather than to an elite only. He claimed that such a wide social grounding had been achieved most effectively by Gothic art:

In antiquity, Christian art was a secondary, derivative, immature style and only in the Romanesque period, when the break between the old and the new worlds occurred, did it expand to cultural and stylistic [slohové ] dimensions ...., then to transform into the Gothic and so to develop into the most typical style. In socialist society, just as in the Gothic, there will be no difference between the ruling art and the underlying current of primary production. Popular [lidové] proletarian art will achieve the same power as that which created the Gothic cathedrals. ${ }^{12}$

This image of the Gothic thus provided Teige with a model for the criterion of lidovost (popular character) that played such a prominent role in his understanding of proletarian art. At the same time it functioned as an image to hold up in contrast to the autonomy of art in bourgeois society. From this perspective, capitalism appeared as a force that had alienated art from its natural function by pushing it along a course of autonomous development and separating it from the everyday concerns and interests of the great mass of people. Proletarian art, by preparing the ground for a modern art that would be lidové, as the Gothic had allegedly been, thus promised a release from the constraints of autonomous art and a return to the direct interconnection of art and everyday life that had been deformed in bourgeois soci-

The Style of the Present: Karel Teige on Constructivism and Poetism 
ety. In this way, Teige implicitly linked the revolutionary action of proletarian art with a process of historical restoration. Proletarian art cleared the path for a return to the historical process of stylistic development that had been interrupted by the autonomy of art under capitalism.

The precedent for Teige's use of the Gothic as a symbol of artistic and stylistic integrity, at least as concerns Czech influences, is easy to locate. ${ }^{13}$ The literary and art critic F.X. Šalda, whom Teige described in 1927 as the "founder of Czech modernism" and the "sign of a new era in our cultural life," had written in 1904 of "the new Gothic, an iron Gothic" portended by modern industrial structures. ${ }^{14}$ For Šalda, the Gothic was simply the most natural image for connoting the enormous potential for social cohesion contained in the true artistic styles. This strong definition of style (which Teige designated with the Czech word sloh, a word lacking the connotations of style as passing fashion or modish design often attached to the word $s t y l)$ implied the power to reveal the various unrelated manifestations of a particular epoch as creating some sort of recognizable whole. In Šalda's words: "Style is nothing other than conscience and consciousness of the whole, consciousness of mutual coherence and connection.... Style is in conflict with everything that breaks this unity, with everything that takes up and isolates details from the whole, links from the chain, beats from the rhythm." ${ }^{15}$ The true styles, by linking isolated details into a whole, thus revealed a distinct and recognizable physiognomy for an entire historical epoch. Šalda's emphasis on the organic totality characterizing such strong artistic styles, in its turn, recalled Nietzsche's description, in the second of the Unzeitgemäße Betrachtungen, of the ideal of "unity of artistic style in all the expressions of the life of a people." 16 Through Šalda, therefore, Teige's early exaltation of the Gothic as "the example of an epoch that is stylistic [slohové] beyond reproach" strongly echoed the ideal of an integrated, creative epoch that Nietzsche had held up in contrast to the weak, historicist culture of the nineteenth century. ${ }^{17}$

Particularly important for Teige's reception of this terminology, however, was Šalda's association of this strong notion of style with a proto-Constructivist discourse. Šalda opposed the integrity of the true styles to the ornamental architecture of historicism and of much of the Czech Secession. A direction for modern architecture, Šalda insisted, would not be found in any new ornamental vocabulary, but rather in the strict logic of industrial structures. Šalda wrote of the power of the impression made "by a huge railway bridge, bare, desolate, without ornament, the sheer embodiment of constructive thought," and concluded that "the new beauty is above all the beauty of purpose, inner law, logic and structure." ${ }^{18}$ Since Šalda was first and foremost a critic of literature and painting, such an emphasis on the style-creating capacity of functional architecture is perhaps surprising. But this language almost certainly reflects the influence of Jan Koterra, a former student of Otto Wagner and one of the groundbreaking architects of Czech modernism with whom Šalda co-edited the Secession journal Volné sméry (Free directions) at the time. ${ }^{19}$ In this manner Šalda set an important precedent for Teige through his application of 
terms stemming from the discourse of early architectural modernism - in particular the terms "ornament" and "eclecticism" - to art and culture in general. ${ }^{20}$

This ideal of the true style served as the context for Teige's account of the failure of art in the bourgeois era. Bourgeois art had never succeeded in creating such a style, but the reason for this was not that artists in bourgeois society had been incapable of creating forms sufficiently beautiful or powerful. Teige had enormous (if selective) respect for the artistic accomplishments of the nineteenth century and often emphasized how groundbreaking many of those accomplishments had been. Nor did Teige, though himself a political radical, blame the failure to develop a true style on the absence of progressive political views among many of the most powerful or aesthetically progressive nineteenth-century artists. No matter how strongly the vision of an individual artist in the nineteenth century may have been motivated by concern for social issues or by outright socialist allegiances (Teige pointed to Gustave Courbet and Vincent Van Gogh as examples), no matter how brilliant may have been their aesthetic achievement, and no matter how pervasive was their influence on the later development of art, all such visions remained those of individuals. No vision was so powerful that it could succeed, through sheer persuasiveness, to force its way to lasting cultural dominance. The vicious circle of bourgeois culture was, indeed, rooted in the fact that it was precisely the aesthetic power of its greatest artists that perpetuated and deepened the most insidious feature of its art: individualism, chaos, and the simultaneity of incompatible visions. To "think" or "will" one's way out of this dilemma was impossible. Every coherent proposal for a way out of the chaos simply took its place as one more monadic vision and thereby increased the chaos.

Teige's explanation of this situation made use of a fairly orthodox Marxist argument. For a true style to gain hold, a minimum level of social continuity was necessary. Previous ruling classes had aimed to preserve the existing relations of production, which constituted the bases of their power. This resistance to change, disastrous as it may have been for the establishment of more just class relations, did produce fertile ground for art. It was precisely the social stagnation of prebourgeois societies that had produced the continuity necessary for the development of a true style. As Karl Marx had observed in The Communist Manifesto, however, the ruling position of the bourgeoisie was no longer based on preserving, but rather on constantly revolutionizing, the relations of production. For Teige, the resulting "overturning of production, ... creating chronic uncertainty and nervousness," and the repetition of cycles of overproduction and economic crisis, all resulted in an analogous "pathological acceleration of the development of modern art, which cannot settle on a definite form of stylistic expression." ${ }^{21}$ This was why, in Teige's view, bourgeois art was ultimately condemned to a chaotic individualism. This was also why the emergence of a true style was contingent not upon strength of aesthetic vision but rather upon revolutionary change of the structure of society. Proletarian art functioned only as an anticipatory vision, or as Teige termed it, a predobraz; the 
true Socialist Gothic could only emerge out of a transformed society: "Style will only come with the establishment of a new social order." 22 Artistic and political revolution were thus linked for Teige not merely by a shared spirit of rebelliousness - which was of course a dominant feature even of bourgeois art - but also by logical necessity.

This account of the necessary stylistic failure of bourgeois art served Teige as the basis for a further thesis: that bourgeois art inevitably tended toward historicism. The pathological acceleration of production displaced art away from the present:

Bourgeois society, which is, on the whole, essentially anaesthetic, provided no art with positive impulses; hence historicism and the Romantic turn to the past, the flight from everyday and class realities, appeared for several decades to be the only salvation for art from the general banalization.... The artist, under the influence of historical and economicpolitical shifts and circumstances, lived cut off from the mass of society. In such a state of emergency, the artist - incapable of living in a vacuum - invents a different society, which belongs to either the past or the future. Acting either as historian or rebel, the artist addresses his work to fictional societies or collectivities. ... [Art] lives off of the spirit of negation, its gaze fixed on the past and the future. ${ }^{23}$

This flight from the present meant that "the connection between art and the spectator was broken." 24 The artist in bourgeois society spoke not to the surrounding society, but in spite of it. Thus pushed into a relation of tension with the present, the bourgeois artist could express critical distance only through flight to spatial or temporal distances, that is, through exoticism or historicism (which Teige viewed as simply variations on a single theme). No matter how justified or critical such negation of the present may have been, the result was indistinguishable from the dreamy nostalgia of the passive bourgeois citizen:

When startled spirits feel the present to be too cruel, too unrelenting, too uncertain, then the perfect beauty of the past makes itself felt.... [People decide to] live in the past or in far-off places, in dream or in reminiscence: in their minds they undertake adventurous voyages to long-past centuries or to the moon, the dead planet. Historicism, exoticism, and the revival of the Rousseauist idyll - these anachronistic forms of Romanticism turn the mind from concrete tasks and present life. ${ }^{25}$

Aesthetic negation, in other words, was socially affirmative. ${ }^{26}$ Or, translated into Teige's emerging Constructivist terms, art under capitalism had lost its functional efficacy. Historicist art (in Teige's broad sense, which included any kind of escapist art), through its forced abnegation of any meaningful role in the structure of capitalist society, became merely ornamental: art could perhaps cover over the banality of the present but could do nothing to effect change.

Teige linked the historicism of bourgeois art to his claim about the endemic individualism of art under capitalism. He wrote: 
The economic conditions of the nineteenth century led society to individualism, to that criminal level of anarchy in life and ideology which made style impossible, corroded the pristine collective pathos of the age of Empire and, through stylistic degeneration, spread the cruel plague of historicizing eclecticism in architecture, transforming cities and streets into a regular museum full of frightful exhibits. ${ }^{27}$

Artistic individualism and architectural eclecticism both consisted in a plurality of self-enclosed and incompatible systems existing side by side. Both betrayed the absence of any reliable criterion to distinguish any one of the systematized historical styles available to the artist or architect as the primary or true style of the age. Teige would almost certainly have regarded the desperate question that served as the title to Heinrich Hübsch's 1828 polemic on architecture-“'In What Style Should We Build?" - as revealing the basic dilemma of style in an age of eclecticism and individualism. ${ }^{28}$ The very possibility of raising such a question indicated that none of the potential answers - Neo-Hellenic, Spitzbogenstil, Rundbogenstil, and so oncould ever be definitive. ${ }^{29}$ The plurality of historicist styles was inescapable: unified style degenerated into mere stylizations, drawing architecture into the conceptual orbit of fashion. ${ }^{30}$ For Teige, a choice for one or another of the available stylistic systems could express nothing other than individual preference, taste, or interpretation.

Teige's critique of historicism thus had two distinct dimensions, corresponding to his use of the terms "ornament" and "eclecticism." The former term delineated the vertical dimension. The cleft separating ornament from structure in historicist architecture was the material expression of a much deeper tension within bourgeois art: the severed connection between art and its public, or between art and its present. Ornament was thus the scarlet letter for the sin of art's autonomy. Further, because ornament was (in the logic of Constructivism) superfluous and merely covered over what was of structural importance, it constituted a deception or historical disguise that hid the true form and identity of the present. Teige's critique of historicism thus had strong affinities with both Loos's equation of ornament and lie and Friedrich Nietzsche's account of the dishonesty, deceptiveness, and protective Innerlichkeit of modern historicist culture. The horizontal dimension of Teige's critique, expressed in the term "eclecticism," referred not to tensions within the individual artwork but rather to the chaotic topography of the cultural landscape as a whole: to the existence of independent aesthetic systems existing side by side yet without any essential connection. Like the "closed system[s] of partial laws" that Georg Lukács identified at around the same time as one of the consequences of reified rationalism, these individual systems were complete in themselves and for this reason mutually exclusive. ${ }^{31}$

Teige's critique of bourgeois art as inherently historicist thus emerged from the context of his theory of proletarian art. Teige in this period (1921 through mid1922) portrayed the present as just starting to emerge from an aesthetic interreg- 
num that stretched back to the beginning of art's autonomy under capitalism. Proletarian art could only guess at and try to lay rough foundations for what would emerge as the next truly lidový and all-encompassing historical style - the Socialist Gothic - to emerge out of the ashes of revolution. The historicism of bourgeois art, therefore, had less to do with the dominance of historical themes than with the situation in this historical interregnum: bourgeois art was historicist precisely because it did not belong to any true historical style. Capitalism had interrupted the great narrative, and the Bolshevik Revolution was the first sign that such a narrative was to be taken up again. Thus Teige's theory of proletarian art implicitly understood revolution in its etymological sense: as a return - at a higher level of development of course - to an earlier state, that is, as a return to history.

At the end of 1922, with the publication of Život II and Teige's increasing focus on Constructivism, this scheme changed. The change followed a fairly natural evolution from Teige's proletarian art rhetoric to his Constructivist terminology. Even within his theory of proletarian art, with its suspicion of the cult of the machine, Teige had begun to introduce functionalist rhetoric in the name of "life" and of the reunion of art with the masses and the everyday. ${ }^{32}$ He stated, for example, that "art is a function of life" and that "in the new world art has a new function. There is no need for [the new art] to serve as an ornament or decoration of life, for the beauty of life, bare and powerful, does not need to be painted over or disfigured with dangling ornaments. ${ }^{33}$ Only a short step was required for this vitalist celebration of the beauty of unadorned life to develop into a purist celebration of the beauty of the unadorned machine: "The beauty of a machine, of an automobile, is the beauty of reality and of the pure form, which doesn't need to be dolled up with ornaments or wreathed with poetry." 34

Underneath this apparently evolutionary rhetorical shift, however, a major change had occurred in the temporal scheme by which Teige defined the avantgarde. Rather than merely anticipating the end of an interregnum, Constructivism already revealed what was coming:

A simple glance at the world is enough to reveal the error of the common statement that we live in a styleless age. A style is emerging continuously right before our eyes, not from aesthetic manifestoes or the interiors of ateliers, but rather from the collective and in many cases anonymous, disciplined, and goal-oriented work of workers and technicians. ${ }^{35}$

With the adoption of Constructivism, Teige felt that the step into the new style no longer lay in the future but had already been taken. Constructivism identified the "designating feature of the contemporary epoch of culture and civilization" and represented, therefore, "the style of the present." 36

This shift in the status of the present altered Teige's view of the past as well. The first indication of the shift was the complete disappearance, by the end of 1922 , of the metaphor of socialist cathedrals and the expectation of a coming Gothic from 
Teige's vocabulary. He now denigrated such rhetoric as an expression of reactionary nostalgia and historicism. ${ }^{37}$ More significant, however, Teige began to use the term "historicism" less and less as a historical category describing nineteenthcentury bourgeois art and increasingly as a term describing a deficient aesthetic structure. The more the term became dehistoricized in this manner, the more Teige began using it to describe all art before Constructivism. Where previously Teige had opposed bourgeois art to the organic unity of Gothic forms, by the mid- and later twenties this contrast between creative Gothic and parasitic neo-Gothic had disappeared. Teige portrayed even medieval art as an unstable "compromise" between aesthetic and utilitarian functions:

This compromise between utilitarian and aesthetic elements strikes a temporary balance on the basis of craft: modern civilization and contemporary industrialization have uprooted this altogether. Such a compromise was the stylistic, historical, essentially medieval trinity of fine arts: architecture as the dominant art, then painting and sculpture. The individual arts then went through a similar process of compromise: the architectural styles [slohy] were various compromises between practical and aesthetic functions, between construction and decoration. Painting was a compromise between depiction and self-regulating color composition: wherever the color harmony took the upper hand over the task of depiction, painting simultaneously became architectural decoration. ${ }^{38}$

Gothic in this formulation was no longer represented as an ideal totality: while its compromise solutions perhaps "balanced" the practical and aesthetic functions more deftly than did bourgeois architecture, they were marked by the same essential tension between construction and ornament. With this shift, even the historical styles came to represent for Teige only superficial or fashionable changes of form:

The most important cultural fact that the intellectual and revolutionary avant-garde owes to the great and celebrated communist revolution is that today we stand at the gates of an enormous, complete, all-encompassing revolution - in this sense the first revolution in art that does not mean a mere exchange of one fashion, one school, one generation, for another. ${ }^{39}$

Constructivism thus no longer occupied the position of a restoration or a modern Gothic. Rather it represented a clean break with all previous "decorative" architecture, a radical new beginning.

Where proletarian art had portrayed the historicism of bourgeois art as the result of its existence within the historical vacuum created by capitalism, Constructivism elided all differences between historicism and the very category of history. Everything that had come before the clean sweep of Constructivism now bore for Teige the stigma of historicism. It was precisely the de-anchoring of the term as a label for a particular phenomenon in nineteenth-century art that allowed Teige to transfer the negative connotations associated with bourgeois historicism to the past as a whole. The temporal scheme supporting Teige's adoption of Constructiv- 
ism thus rested on a paradox: Teige's elision of history and historicism in effect implied that the entire history of culture had unfolded in a historical vacuum. Only with the new instauration of Constructivism, that is, with the radical rejection of the past as such, could a "truly" historical epoch commence.

\section{The Dead Ends of Dualism}

Constructivism had barely assumed center stage in Teige's theoretical discourse when it suddenly had to share the spotlight. Over the course of 1923, the credo of Poetism - Czech culture's most original contribution to the interwar avantgarde - emerged as a counterpart to Constructivism. While Poetism was formed from a confluence of sources (Teige and the poet Vítězslav Nezval being the most important), the conjoining of Constructivism and Poetism into a double program was entirely Teige's contribution. ${ }^{40}$

At least initially, the conjunction seems strange indeed. While in this period Teige was establishing an international reputation as one of the most ideologically severe proponents of Constructivism, in Czechoslovakia he was becoming equally known for his effusive remarks on Poetism. "The art that Poetism brings is casual, exuberant, fantastic, playful, unheroic, and amorous," he wrote. As a movement, Poetism is "nothing other than a loving inclination toward life and all of its manifestations, a passion for modernity, ... nothing other than happiness, love and poetry, the things of paradise." As a practice, Poetism "has shifted [its emphasis] away from stuffy workshops and ateliers and onto the experiences and beauties of life; it reveals a path coming from and going nowhere, tracing circles in a wonderfully fragrant park, because that is the path of life." ${ }^{41}$ This Poetist paradise, with its eudemonism and emphasis on anti-instrumental action, is clearly a very different place from that of Constructivism, which was characterized by the "anonymous, disciplined and directed work of workers and technicians." ${ }^{\text {42 }}$ The terms appear to be contradictory, not complementary. Where Constructivism demanded discipline, order, and a pragmatic outlook, Poetism celebrated the free play of imagination and the carefree indulgence of the senses. Essentially, the tension between the terms resulted from the simultaneous exaltation of hyperrationality and lyrical irrationality.

Teige nevertheless insisted (at least until the mid-twenties) that Constructivism and Poetism were both the logical result of a single phenomenon: the withering of the category of art as such. Teige claimed that Constructivism, through its rejection of "a priori aesthetics," "traditional formulae," and "formalism," enacted nothing less than "the systematic liquidation of art." ${ }^{43}$ Analogously, Poetism rejected both the professional artist and the traditional genres and media of art, claiming that "the new art will cease to be art," and extolling the clown, the traveler, the amateur athlete, and the like as the unacknowledged legislators of the new age. ${ }^{44}$ 
Glearly, Teige's rejection of art-following a pattern not uncommon for the historical avant-garde - was understood as a renewal or reinvigoration of the aesthetic. ${ }^{45}$ Constructivism and Poetism were to imbue everyday life with aesthetic efficacy through a transformation of modes and habits of perception. This sublation of the category of art united Constructivism and Poetism in a liberatory act that Teige portrayed metaphorically:

The new, endless, brilliant beauty of the world is the daughter of contemporary life. It was not born from aesthetic speculation, from the romantic atelier mentality, but simply results from purposeful, disciplined, positive production and from the life activity of humankind. It has not taken root in cathedrals or galleries; out on the streets, in the architecture of the cities, in the invigorating green of the parks, in the bustle of the harbors and in the furnaces of industry, which provide for our primary needs - this is where the new art finds its home. It does not dispense formalized prescriptions: modern forms and formulations are the result of purposeful work, produced with perfected methods under the dictates of purpose and economics. This new beauty has taken the engineer's equation and filled it with poetic vision. ${ }^{46}$

The Poetist liberation of art from the confines of the museums and cathedrals thus led not simply onto the streets, into the city, and onto the stage of modern life. It led further: to the fringes of the city, to the factories and housing projects, redeeming these zones from the stigma of being extra-aesthetic. Thus Poetism's new perception, its new beauty, led directly to those urban areas developing under the aegis of Constructivism, expressing the aesthetic efficacy promised by Constructivism's implementation of the style of the present. This topographical metaphor of a city no longer divided into representative zones of aesthetic escape and banal zones of material necessity - of center versus surroundings - is the clearest expression of Teige's vision of Constructivism and Poetism as forming an integrated whole.

Teige's conjoining of Constructivism and Poetism thus represented a clearly holistic gesture. ${ }^{47}$ This holism stands out especially clearly when the context of his critique of historicism is recalled. The dialectical joining of Constructivism and Poetism was directly motivated by the desire to overcome the eclecticism dividing cities into zones governed by different aesthetic principles. With the discovery of beauty in the functional, and with the production of aesthetically pleasing objects that were integrated with everyday life through their functionality, the dual program aimed at ending the division of modern culture into structural and decorative realms. The dualism, paradoxically, was to inaugurate the "unity of artistic style" Nietzsche had called for half a century earlier.

The radicality of this totalizing drive - as well as the outline of the aporia to which it led-emerged in full force during Teige's polemic with Le Corbusier over the Mundaneum project. Le Corbusier felt Teige had denied precisely the necessity of such a holistic vision, that he had failed to appreciate the necessity of architecture's appealing not only to the brain but also to the passions. Functionality was only the first step for the architect: what transformed a mere building into architec- 
ture was the further step whereby the architect addressed the task of making the functional structure beautiful as well. Le Corbusier concluded that "the function beauty is independent of the function utility; they are two different things." 48 Teige, it appeared, had overlooked the beauty function.

Putting the polemic with Le Corbusier in the context of Teige's other writings, however, makes clear that Le Corbusier misunderstood Teige's point. Teige was quite as committed as Le Corbusier to the precept that avant-garde architecture be beautiful. His disagreement, however, was precisely with the postulate of an independent beauty function. Teige insisted that architectural beauty could only originate from the strictest functionality. Four years before the Mundaneum polemic Teige had written:

It could be objected that certain machines, even though perfectly functional, may still be ungainly or hideous. ... We could respond that an ungainly machine calls directly for further perfecting, that its ugliness is a symptom of inadequacy. We assert that the more a machine is perfected, the more beautiful it will be. And it will be absolutely perfected, and consequently beautiful, only if the perfection of its utility, and not beauty, has been the constructer's sole interest. ${ }^{49}$

In other words, beauty would be found only when it was not sought. ${ }^{50}$ Teige's problem with Le Corbusier's Mundaneum project thus had nothing to do with the beauty of the end result, but with the act of seeking beauty somewhere outside of function:

According to Le Corbusier, architecture as art believes that its calling begins where construction ends, namely with the rational solution and products of the engineer. It aspires to eternity, while the engineer responds to actuality. ... In short, according to this argument, to become dignified as architecture, there must be added some "plus" to the rational solution. Now this "plus" can either help utility and strengthen function, in which case it is simply utility and function and is not a "plus," or hinder it, in which case it is of course a minus. Further, it can neither help nor hinder, in which case it is superfluous and unnecessary, and that is a minus as well. ${ }^{51}$

In Teige's view, this structure of the "plus," or of a supplement added on to something already whole, revealed that Le Corbusier's beauty function was nothing other than a more subtle form of ornamentation. While Le Corbusier felt that the beauty function completed the work begun by the utility function and thereby created a whole, Teige perceived an already self-sufficient whole being destroyed through the addition of a superfluous supplement. Hence Le Corbusier's “obvious historicism": the claim that one added aesthetic value after completion of the functional structure was for Teige the theoretical equivalent of completing a building by covering it with, say, a neo-Renaissance façade.

Teige's hard-nosed advocacy of the strictest functionalism, therefore, was not the expression of a dry, humorless rationalist applying "police measures" against those with greater visions for architecture, as Le Corbusier had suggested. Teige's 
vision of the promise held by Constructivism was just as grandiose as Le Corbusier's, as the premise of a "style of the present" makes clear. His expectation of a new beauty was also no less intense, as the credo of Poetism expressed. Indeed Teige went so far as to claim that the rigor of functionalism, by eliminating the stifling formalism represented by an ornamentalizing beauty function, would return "humanism" to architectural form. ${ }^{52}$ The strictness of Teige's functionalism was, therefore, precisely the result of the enormity of his claims for Constructivism: the claim that it would heal basic diremptions of modern culture, the insidiousness of which was made clear by the way eclecticism and ornamentation could creep into the work even of a modern master like Le Corbusier. The radicality of Teige's functionalist rationalism issued directly from the radicality of his totalizing vision.

This utopian hope for an integrated modernist culture clearly caught Teige in a vicious circle, expressed in the paradoxes that Le Corbusier refused to admit: a new beauty would result only from a radical elimination of the independent beauty function, and a humanist architecture would emerge only from the insistence that architecture take its measure from the machine and its function. The ideals of beauty and humanism thus became unattainable the moment they were openly named; they needed to remain, as it were, always beyond the horizon if they were ever to be reached. These paradoxes, however, are not the sign of a logical failure on Teige's part. Indeed, given the functionalist premise, Teige's position is much more consistent than Le Corbusier's appeal to architecture as "spiritual food." "53 These logical quandaries resulted rather from precisely the meticulousness of Teige's functionalist logic and the extremity of his totalizing claims.

The final expression of this vicious circle was, of course, Teige's dual program itself. Why did the effort to theorize avant-garde culture as an organic, totalizing unity take the form of a dualism of Constructivism and Poetism? How could this programmatic pairing of terms avoid repeating the historicist dualism of structure and ornament that Teige had all along taken such pains to eliminate? Was not Poetism simply a disguised form of the independent beauty function that Teige had criticized so vehemently in Le Corbusier? Appeals to the dialectical unity of the terms are obviously insufficient. The dualism degenerates too easily into undialectical formulations, several of which have become commonplaces in the secondary literature on Teige. Primary among these are formulations favoring one pole of the dualism as the "primary" element of Teige's program and viewing the other pole as the logical "complement" to the first. ${ }^{54}$ Other formulations view the dualism as an attempt to achieve comprehensiveness through a simple proclamation of the unity of opposites. ${ }^{55}$ Such characterizations never raise the most challenging and most productive questions for an understanding of the Constructivism/Poetism conjunction, and those are Teige's own questions: how does this conjunction avoid repeating the historicist dualism it rejected at the outset, and, if it fails to do so, what antinomies lie behind this situation?

The difficulty with the claim of dialectical unity emerges clearly from the most

The Style of the Present: Karel Teige on Constructivism and Poetism 
famous image chosen by Teige to express such unity. He wrote, "Poetism is the crown of life, the basis of which is Constructivism.... It builds on Constructivism's groundplan. ${ }^{" 56}$ The image is clearly meant to express the interconnection of base and crown, and the incompleteness of either element taken independently. But, like Marx's metaphor of base and superstructure to which it alludes, the image seems equally effective in suggesting the division between or the independent existence of the two elements. ${ }^{57}$ In fact, Teige's image compulsively reproduces the fate of Marx's: it slips from an expression of dialectical unity to one of static dualism. Teige's critique of historicism provides a vocabulary to describe this slippage: the conceptual model of base and superstructure all too easily degenerates into the model of structure and ornament. Through such slippage, the second element (Poetism, or for Marx, the superstructure) appears not as the dialectical counterpart and completion of the first but rather as something supplemental, unnecessary, or parasitic.

Teige's attempt to stipulate the unity of Constructivism and Poetism thus repeated a logical conundrum encountered by Marx when he attempted to formulate a theory of nonideological, that is, materialist consciousness. Constructivism provided Teige with the same firm logical ground that Marx felt he held with the theory of historical materialism. For both Marx and Teige, this firm ground seemed to represent a promised land: the rigor, the hardheaded sense of reality opened up a vision of harmony and integration of the mental and the material. Poetism was Teige's name for this promise of harmony. But Poetism presented the same problem that the premise of a nonideological consciousness did for Marx. Either Poetism was "there," in which case one could point to it but it degenerated into simply another artistic program, an a priori aesthetic system, or an ornamental layer; or Poetism was "not there," in which case it was Constructivism alone. Precisely the rigorous internal consistency of Constructivism, however, was what had caused Poetism, as the experience of harmony, to appear in the first place, and thus the vicious circle began again. The promised middle ground symbolized by the images of base and superstructure, foundation and crown, emerged as a true utopia: it was nowhere.

Teige's dualism thus should not be interpreted as consisting of two poles of equivalent status or as a willful combination of opposed programs. Constructivism contained a certain corpus of principles deriving from the central criterion of functionality, but Poetism was by its nature averse to programmatic formulation. In response to the question "what is Poetism?" Teige had responded that it "is casual, exuberant, fantastic, playful, unheroic and amorous." Poetism was a "life atmosphere," a modus vivendi, and no more precise definition was possible. ${ }^{58}$ Teige's second Poetist manifesto in fact took aim precisely at the formulation of Poetist principles, which Teige felt were leading away from the molten experience itself. From a series of metaphors or an inspiring vision, Teige feared Poetism by the late 1920s was turning into a movement or school, that is, it was ossifying into a formalism. ${ }^{59}$ 
Thus the relation between Poetism and Constructivism was not one between counterparts or equivalent items in a series. Teige's program was not strictly speaking a dual one because Poetism could have no program.

The dilemma of this dualism therefore could not be avoided: no more moderate formulation or adjustment to the dual program could have saved Teige from the reemergence of the dualism he had sought to overcome. Constructivism was to implement its radically totalizing vision by rooting out eclecticism and ornament through rigorous application of the criterion of functionality. Poetism, on the other hand, had no corresponding criterion or program because it represented simply a manner of perception, a modus vivendi. In Teige's formulation, Poetism was nothing more or less than the enthusiastic reception of the world created by Constructivism. Poetism was therefore the necessary result of Constructivism fulfilled: it was the experience of a world in which totality had been achieved. Poetism would have arisen in theory even if Teige had never named it in practice. For Poetism - which destroyed the pristine purity of the totality claimed by Constructivism - emerged spontaneously from precisely those totalizing claims.

Poetism's spontaneous emergence from the claims of Constructivism was the awkward reminder of Constructivism's origin. The new instauration and rejection of all historical models upon which the emergence of Constructivism as the style of the present was predicated still bore the sign of their origin as the anticipation of a modern Gothic. The original complaint against bourgeois historicism had been its lack of historical plenitude: the interregnum signaled by the failure to develop a true style. But Constructivism had taken this account of the failure of historicism and made of it the failure of history; or conversely, the hopes originally placed in a renewal had been displaced into a faith in the new. Constructivism's style of the present thus harbored within itself this paradox: although Constructivism called for a rigorous rejection of the historical, the resulting products were still understood as re-inscriptions into history. Poetism expressed this paradox. Poetism was the celebration of the new instauration and the achievement of a totality, but a celebration that simultaneously marred that totality and revealed that the instauration had taken the form rejected at the outset as the mark of historicism. The elision of historicism and history not only is characteristic of Teige's Constructivism but also is definitive of the avant-garde hostility to the past. Poetism reveals the bad conscience of this hostility: its inseparability from historical nostalgia. The avantgarde critique of historicism, equating historical plenitude with the rejection of history, thus took the form of critique of a dualism it was condemned to repeat. 


\section{Notes}

1. Karel Teige, "Mundaneum," trans. Ladislav Holovsky, Elizabeth Holovsky, and Lubomir Dolezel, Oppositions 4 (1974): 89. Originally published in Stavba 7, no. 10 (March 1929): 145-55. Teige's use of the term "historicism" here and elsewhere was primarily informed by architectural debates over the aesthetic status of historical decorative systems. Nonetheless, the term echoes ominously for Teige with everything he felt was insidious about nineteenth-century "academic" culture. The manner in which Teige transformed the term into a loose yet damning label for a failed aesthetic framework will be discussed later in this essay.

2. As George Baird points out, that Le Corbusier responded directly to Teige's critique was in itself unusual; "Architecture and Politics: A Polemical Dispute," Oppositions 4 (1974): 80. That Le Corbusier took the issue not only seriously but also personally seems clear from the way he peppered his response with amiable apostrophes and repeated appeals to Teige's "poetic" nature.

3. Le Corbusier, "In Defense of Architecture," trans. Nancy Bray et al., Oppositions 4 (1974): 94. Originally published in Czech in Musaion 2 (1931): 27-52.

4. George Baird, The Space of Appearance (Cambridge, 1995), 133 and 70; Kenneth Frampton, "The Humanist v. The Utilitarian Ideal," Architectural Design 38, no. 3 (1968): 133 36; and see also his Modern Architecture: A Critical History, 3rd ed. (London, 1992), 160. Also see Rostislav Švácha, "Before and After the Mundaneum: Karel Teige as Theoretician of the Architectural Avant-Garde," in Eric Dluhosch and Rostislav Švácha, eds., Karel Teige, 1900-1951: L'Enfant Terrible of the Czech Modernist Avant-Garde (Cambridge, 1999), 107-39. Švácha characterizes Teige's "dogmatic stance" as that of a "blind doctrinaire" (108).

5. On Devétsil, see Derek Sayer, The Coasts of Bohemia: A Czech History (Princeton, 1998), 208-15; and František Šmejkal and Rostislav Švácha, eds., Devětsil: Czech Avant-Garde Art, Architecture, and Design of the 1920s and 1930s (Oxford, 1990). For English-language accounts of Poetism, see Karel Srp, "Karel Teige in the Twenties: The Moment of Sweet Ejaculation," and Lenka Bydžovská, "The Avant-Garde Ideal of Poiēsis: Poetism and Artificialism During the Late 1920s," both in Dluhosch and Švácha, Karel Teige, 1900-1951, 11-45 and 47-63, respectively; and Esther Levinger, "Czech AvantGarde Art: Poetry for the Five Senses," Art Bulletin 81, no. 3 (1999): 513-32. For a recent and detailed examination of one of the major artistic products of Poetism, see Matthew S. Witkovsky, "Staging Language: Milča Mayerová and the Czech Book Alphabet," Art Bulletin 86, no. 1 (2004): 114-35.

6. Teige's reference points for Poetism underwent a general shift over the course of the twenties from mass culture to high modernism, and from critiquing to embracing aesthetic autonomy. This shift - deeply connected with Teige's developing notion of an "aesthetic function"- clearly should make one wary of speaking of Poetism as an unchanging body of theory.

7. The scale of this challenge seems confirmed by the fact that even today secondary literature on Teige generally foregrounds one or the other side of his thought (I will return to this issue later). Teige's "unified field theory" of the avant-garde responded to a cru- 
cial phase of both diversification and consolidation within the European avant-garde. As Timothy Benson has pointed out, the early twenties saw a range of new inflections in avant-garde practice emerge into prominence, especially among the new Central European nations. This explosion of national variations both confirmed the existence of a broad international consensus behind avant-garde culture and simultaneously threatened to fragment into a mosaic of particular visions. Thus the urgency of shoring up an "intentional community" through the notion of an "international style" uniting disparate avant-garde activities became increasingly apparent; see Timothy O. Benson, "Exchange and Transformation: The Internationalization of the Avant-Garde[s] in Central Europe," in Timothy O. Benson, ed., Central European Avant-Gardes: Exchange and Transformation, 1910-1930 (Cambridge, 2002), 49. Just such a sense of urgency motivated Teige's rhetoric about Constructivism as the "style of the present." For broader explication of the national contexts of the different Central and Eastern European avant-gardes (and on the intersections of modernism and nationalism in the region), see S. A. Mansbach, Modern Art in Eastern Europe: From the Baltic to the Balkans, ca. 1890-1939 (Cambridge, 1999).

8. The period 1929-30 was pivotal in this respect. It not only witnessed the disbanding of Devétsil during the course of the so-called Generational Discussion but, for Teige, also culminated in the breakdown of the Constructivism/ Poetism dualism, at least partially due to the contradiction at issue here. Teige came to see the heart of the Generational Discussion in the "crisis of criteria" characterizing avant-garde artistic theory (Poetism) in contrast to the conceptual clarity of avant-garde architectural theory (Constructivism). For the next several years Teige focused his attention almost exclusively on architectural theory, and when he did return in 1934 to artistic theory in the form of Surrealism, he did not attempt explicitly to resuscitate the unified theory of the avantgarde that had been so characteristic of and problematic for his work in the twenties; see Rostislav Švácha, "Karel Teige and the Devětsil Architects," Rassegna 53 (1993): 14, and esp. Hana Císarová, "Surrealism and Functionalism: Teige's Dual Way" in the same issue of Rassegna, 78-87.

While this breakdown comes at more or less the same time as the Mundaneum polemic, I do not think it supports the scheme of a straightforward "utilitarian shift." Teige did not abandon the overriding aesthetic claims associated with rigorous functionalism so much as sublimate them, having clearly realized the failure of his previous formulation of the issue. Further, even during the period when the Constructivism/Poetism paradigm was triumphant Teige's strict functionalism had often been perceived as "utilitarian," as is evidenced by his ongoing conflicts with many of the Devétsil architects. See Rostislav Švácha, The Architecture of New Prague, 1895-1945, trans. Alexandra Büchler (Cambridge, 1995), 275-76.

9. See, e.g., Karel Teige, "Nové umění a lidová tvorba" (The new art and folk production), in Štěpán Vlašín, ed., Avantgarda známá a neznámá (Prague, 1971), esp. 1:152 and 154.

10. The winter of 1922-23 was decisive for this shift. Toward the end of 1922, Devétsil released the Revolučni sborník Devětsil (Devětsil revolutionary anthology); Karel Teige and Jaroslav Seifert, eds. (Prague, 1922). Teige's theoretical articles in this volume attempted to redefine a "new proletarian art" that already betrayed the gravitational attraction of Le Corbusier's Purism and Soviet Constructivism. The major break, however, came shortly afterwards, with the release of a second Devétsil collective volume: Život II: Nové uméní, konstrukce, soudobá intelektuelni aktivita (Life II: The new art, construction, contemporary intellectual activity), ed. Jaromír Krejcar (Prague, 1922). Zivot II utilized a variety of nonstandard layouts and superimposed typefaces, with illustrations 
juxtaposing ocean liners to Tibetan architecture, and modernist sculpture to Native American totem poles or snowplow trains, very much in line with the "new spirit" proclaimed shortly before by Le Corbusier. The influence of the editor, Krejcar, one of the most innovative architects of the Czech avant-garde, must also be taken into account in regard to this shift in emphasis; see Rostislav Švácha, "The Life and Work of the Architect Jaromír Krejcar," in Jaromír Krejcar, 1895-1949 (Prague, 1995), 42-45; and Sayer, Coasts of Bohemia, 212-13.

11. See, e.g., Jiří Wolker [and K. Teige], "Proletářské umění” (Proletarian art, [1922]) in Dílo Fiŕho Wolkera, ed. Miloslav Novotný, 5th ed. (Prague, 1930), 1:292; and Vladislav Vančura, "Nové umění" (The new art), Host 3 (1923): 120.

12. Karel Teige, "Nové umění proletářské" (The new proletarian art [1922]) originally in Revolučni sborník Devétsil, here quoted from Karel Teige, Výbor z díla, ed. Jiř́i Brabec et al. (Prague, 1966), 1:60-61. (This edition hereinafter referred to as "VzD" followed by a volume number.) All translations herein, unless an English edition is cited, are my own.

13. This symbolic image of the Gothic can, of course, be traced back at least to John Ruskin and also appears in other contexts of the early avant-garde. A relevant example is Walter Gropius's 1919 Bauhaus program, which called for "a new guild of craftsmen" that would forge the "new structure of the future, which will embrace architecture and sculpture and painting in one unity and which will one day rise toward heaven from the hands of a million workers like the crystal symbol of a new faith"; in Ulrich Conrads, ed., Programs and Manifestoes on 20th-Century Architecture (Cambridge, 1970), 49. Gropius's text was illustrated with a woodcut by Lyonel Feininger depicting a radiant cathedral. See the discussion in Karsten Harries, The Ethical Function of Architecture (Cambridge, 1997), 106-7.

14. Teige's quotations are from "Vůdce české moderny" (The leaders of Czech modernism), in $V z D / \mathrm{I}, 248$. Šalda's quotation is from "Nová krása - její genese a charakter" (The new beauty - its genesis and character), in Boje o zitrek: Meditace a rapsodie, 1898 1904, here quoted from Soubor díla F. X. Saldy, ed. Jan Mukařovský et al., 22 vols. (Prague, 1948), 1:97. On Šalda's influence on the Devétsil generation, see also Vratislav Effenberger, "Nové umění," in $V z D / \mathrm{I}, 582$.

15. Šalda, "Nová krása," 93. Šalda - in contrast to Teige's practice — does use the word styl in this passage.

16. Friedrich Nietzsche, Unzeitgemäße Betrachtungen II: "Vom Nutzen und Nachtheil der Historie für das Leben," in Kritische Studienausgabe, ed. Giorgio Colli and Mazzino Montinari, 15 Vols. (Munich, 1988), 1:274. On the influence of the Unzeitgemäße Betrachtungen on Šalda, and on how Nietzsche's critique of historicism became intertwined with Šalda's critique of the formal eclecticism of the Lumír generation, see Vladimír Kafka, "F. X. Šalda a německá literatura," in Studie a úvahy o némecké literatuře (Prague, 1995), 32, 45, and 89. Equally evident here is Šalda's indebtedness to Nietzsche's wellknown description of the "style of literary decadence" in Der Fall Wagner, in Kritische Studienausgabe, 6:27.

17. Karel Teige, "Umění přítomnosti” (The art of the present), in Krejcar, Život II, 132. For an excellent discussion of the philosophical ramifications of this concept of style, see Harries, The Ethical Function of Architecture, esp. 64-65. Teige's early concept of sloh in any event shows clear affinities with what Louis Althusser has critiqued as "an expressive totality, i.e., a totality all of whose parts are so many 'total parts,' each expressing the others, and each expressing the social totality that contains them"; Reading Capital, trans. Ben Brewster (London, 1997), 94, emphasis in original. Althusser's critique is 
central for a number of commentators who attribute to modernism a decentered model of subjectivity radically hostile to expressive totalities; see, e.g., K. Michael Hays, Modernism and the Posthumanist Subject (Cambridge, 1992), 14; and Stefan Jonsson, Subject Without Nation: Robert Musil and the History of Modern Identity (Durham, N.C., 2000), esp. chap. 1. Teige's case, however, suggests that the concept of expressive totality must be handled with caution: while Teige's later radical functionalism allies him with the "antiexpressive" position of an architect such as Hannes Meyer (a major explorer of posthumanist subjectivity in Hays's account), it also directly cited humanist topoi and (as I hope to show here) developed with a certain logical rigor out of the earlier "expressive" paradigm.

18. Šalda, "Nová krása," 97-98. See also Šalda's 1909 note upon the opening of the monumental Secession-style Municipal House in Prague: "So the scaffolding has come down and now one can clearly see what will be representing [Prague]: . . . something immensely petty despite its enormous size; a sort of magazine kiosk on a larger scale. And next to it looms that fantastic, black Gothic tower, the [fifteenth-century] Powder Tower, that pithy verse from a stone poem, masculine and elemental like the age from which it comes. It does not represent anything: it simply is what it is. Standing before it, you feel shame from the bottom of your soul for the representational piece of posterboard next to it and for the age with a paper soul [ . ., which] forgets that before one can represent, one must be something"; F.X. Šalda, "Representační dům pražský," in Soubor díla F. X. Šaldy, 16:433.

19. Teige regarded Jan Kotěra as the only figure of the Czech turn-of-the-century rivaling Šalda in significance (see $V z D / I, 246-48$ ). On Kotěra's influence on Šalda, see Petr Wittlich, Prague Fin de Siècle, trans. Maev de la Guardia (Paris, 1992), 139.

20. Further, as several commentators have pointed out, Šalda's transmission of such protoConstructivist concerns must be added to the influences on the early Teige alongside Soviet Constructivism and French Purism (Le Corbusier). See Markéta Brousek, Der Poetismus. Die Lehrjahre der tschechischen Avantgarde und ihrer marxistischen Kritiker (Munich, 1975), 103; Švácha, "Before and After the Mundaneum," 109; and Eric Dluhosch, "Translator's Introduction," in Karel Teige, The Minimum Dwelling, ed. and trans. Eric Dluhosch (Cambridge, 2002), xv-xvi.

21. Teige, "Umění přítomnosti," 127. See also Karel Teige, "Doba a umění," (Art and the age), in Stavba a báseñ: Uméni dnes a zítra (Building and poem: Art today and tomorrow) (Prague, 1927), 29.

22. Teige, "Umění přítomnosti," 127. See also Teige, "Nové umění proletářské," 62-63, and Karel Teige, "Umění dnes a zítra" (Art today and tomorrow) in Teige and Seifert, Revolučni sborník Devětsil, 198.

23. Teige, "Nové umění proletářské," 44-45. See also Teige, "Doba a umění," 39.

24. Teige, "Umění dnes a zítra," 189.

25. Teige, "Doba a umění," 31. It should be pointed out that exoticism, the excitement of long-distance travel, and the discovery of the "primitive" were also major ingredients of Poetist rhetoric in the mid-twenties. Teige never explicitly contrasted these two forms of exoticism. Poetist exoticism, however, was largely driven by the parallels between the ultra-exotic and the ultramodern: Tibetan architecture was inspiring largely for its similarities to the American skyscraper; the excitement of discovering far-off lands was inseparable from the excitement over the ocean liner or airplane that brought one there. In this way, exoticism, technology, and cosmopolitanism were always linked themes in Teige's texts on Poetism. They expressed the development of closer ties between previously isolated cultures and peoples as well as the emergence of a "world culture" of

The Style of the Present: Karel Teige on Constructivism and Poetism 
modernism. In this, Poetist exoticism reflects James Clifford's description of "the discovery of things 'nègre' by the European avant-garde[, which was] mediated by an imaginary America, a land of noble savages simultaneously standing for the past and future of humanity - a perfect affinity of primitive and modern"; The Predicament of Culture: Twentieth-Century Ethnography, Literature, and Art (Cambridge, 1988), 198.

26. For a comparison of Teige's sociology of art with Herbert Marcuse's account of affirmative art, see Květoslav Chvatík, "Karel Teige a Herbert Marcuse o společenské funkci umění," in Melancholie a vzdor: Eseje o moderni české literatuře (Prague, 1992), 57-74. (German version: "Herbert Marcuse und Karel Teige über die gesellschaftliche Funktion der Kunst," in Axel Honneth and Albrecht Wellmer, eds., Die Frankfurter Schule und die Folgen [Berlin, 1986].)

27. Teige, "Nové umění proletářské," 44. See also Teige, "Doba a umění," 39.

28. See Heinrich Hübsch et al., In What Style Should We Build? The German Debate on Architectural Style, trans. Wolfgang Hermann (Santa Monica, Calif., 1992).

29. Teige would certainly have found satisfaction in the fact that in 1898 - seventy years after Hübsch's text-Czech architects in the leading art journal Volné sméry on the Prague Architecture and Engineering Exhibition posed the exact same question. See Otakar Nový, Česká architektonická avantgarda (Prague, 1998), 80.

30. See Karel Teige, "K teorii konstruktivismu" (On constructivist theory), in VzD/I, 363; and Karel Teige, "Výtvarná práce sovětského Ruska" (Creative work in Soviet Russia), in $V z D / \mathrm{I}, 272$.

31. Georg Lukács, History and Class Consciousness, trans. Rodney Livingstone (Cambridge, 1971), 104 .

32. Teige in this period was critical not only of the Italian Futurists for their aestheticization of the technology of war (see, e.g, Karel Teige, "Obrazy a předobrazy" [Images and fore-images], in $V z D / \mathrm{I}, 26)$ but also of the "machinism" he felt characterized much of the Soviet avant-garde (see Teige's review of Ilya Ehrenburg's And Yet It Moves, quoted in $V z D / \mathrm{I}, 520)$.

33. Teige, "Nové umění proletářské," 52, and Teige, "Umění dnes a zítra," 199. Emphasis in original.

34. Karel Teige, "Foto Kino Film," in Život II, 158.

35. Karel Teige, "Toward a New Architecture," in Karel Teige, Modern Architecture in Czechoslovakia, trans. Irena Žantovská Murray and David Britt (Los Angeles, 2000), 309. Translation modified. In Czech: "K nové architektuře," in $V z D / \mathrm{I}, 112$.

36. Karel Teige, "Constructivism and the Liquidation of 'Art," " in Teige, Modern Architecture, 331. Translation modified. In Czech: "Konstruktivismus a likvidace 'umění,'” in $V z D / I, 129$. Emphasis in original. Such a proclamation of course has clear precedents: most directly Le Corbusier in Vers une architecture, as well as Adolf Loos. See, e.g., the discussions in Kenneth Frampton, Le Corbusier (New York, 2001), 31, and Hilde Heynen, Architecture and Modernity: A Critique (Cambridge, 1999), 78.

37. See Nový, Česká architektonická avantgarda, 188. Teige later singled out for criticism along these lines the early Bauhaus under Gropius, despite the fact that proletarian art had used similar imagery at that time. See Karel Teige, "Ten Years of the Bauhaus," in Teige, Modern Architecture, 318. In Czech: "Deset let Bauhausu," in VzD/I, 478.

38. Karel Teige, "Toward a Theory of Constructivism," in Teige, Modern Architecture, 288. Translation modified. In Czech: "K teorii konstruktivismu," in $V z D / \mathrm{I}, 361-62$.

39. Teige, "Výtvarná práce sovětského Ruska," 272.

40. On this double origin of Poetism, see Brousek, Der Poetismus, 81-87. Bedřich Václavek (also a member of Devétsil in the twenties, although in the thirties a proponent of Social- 
ist Realism), following Teige, developed a similar dual program around the poles of "pure" and "purposeful" art (čistá a úćelná tvorba); see Oleg Sus, "Estetické antinomie v české levé avantgardě," in Estetické problémy pod napétím: meziválečná avantgarda, surrealismus, levice (Prague, 1992), 12-34.

41. Karel Teige, "Poetism," trans. Alexandra Büchler, in Dluhosch and Švácha, Karel Teige, 1900-1951, 68. Translation modified. In Czech: "Poetismus," in VzD/I, 123-24. This text from 1924 constitutes Teige's classic statement on Poetism. It is often referred to as the "first Poetist Manifesto" to distinguish it from Teige's 1928 "Manifest Poetismu," in $V z D / \mathrm{I}, 323-59$; parts of the second manifesto have been translated by Gerald Turner under the title "Excerpts from 'Poetism Manifesto"" in Timothy O. Benson and Éva Forgács, eds., Between Worlds: A Sourcebook of Central European Avant-Gardes, 1910-1930 (Cambridge, 2002), 593-601. Teige's simultaneous reputation in international circles as a strict functionalist was largely founded on his work for the architectural journal Stavba. Teige became editor of Stavba in 1923 and quickly turned it into an important European forum for Constructivism; see Vratislav Effenberger, "Nové umění," 593; and Švácha, Architecture of New Prague, 328.

42. Teige, "Toward a New Architecture," 309 (translation modified); "K nové architekture," 112.

43. Teige, "Constructivism and the Liquidation of 'Art,", 331 (translation modified); "Konstruktivismus a likvidace 'umění,", 129-30. Emphasis in original. In Teige's account, Suprematism had performed the final liquidation of painting: Kasimir Malevich's white canvas had brought abstraction to its ne plus ultra. Suprematism could go no further, and consequently Malevich devoted himself to analytical work, and Alexander Rodchenko and other leading Suprematists moved on to Constructivism, for which the liquidation of art was no longer the goal but the starting point; see Karel Teige, "Dnešní výtvarná práce sovětského Ruska" (Current creative work in Soviet Russia), in SSSR: úvahy, kritiky, poznámky, ed. Bohumil Mathesius (Prague, 1926), 157-58.

44. This is a frequently repeated phrase in Teige's writings of the mid-twenties. Teige took it over from the Soviet Constructivist Ilya Ehrenburg. On the parallel between Constructivism's and Poetism's respective "liquidations" of art, see Dirk Uffelmann, "Maximální funkčnost: Architektur und Poesie in der Theorie Karel Teiges 1924-1930 —Ein Baustein zur Genealogie totalen Denkens," Österreichische Osthefte 39, no. 3 (1997): 394.

45. See, e.g., Peter Bürger, The Theory of the Avant-Garde, trans. Michael Shaw (Minneapolis, 1984), 49 and 106 n. 10. Also see the discussion of Bürger's claims in Astradur Eysteinsson, The Concept of Modernism (Ithaca, 1990), 171-72. This point is made in regard to Teige by Švácha, "Before and After the Mundaneum," 119, and by Vladímir Müller, Der Poetismus. Das Programm und die Hauptverfahren der tschechischen literarischen Avantgarde der zwanziger Jahre (Munich, 1978), 34.

46. Teige, "Poetism," 66-67 (translation modified); "Poetismus," 122.

47. Uffelmann states that "Teiges Denken zwischen 1924 und 1928 kann . . . als ontologisches Modell einer Lebensphilosophie . . . mit totalem Anspruch verstanden werden"; "Maximální funkčnost," 386.

48. Le Corbusier, "In Defense of Architecture," 98.

49. Teige, "Constructivism and the Liquidation of 'Art,", 339 (translation modified); "Konstruktivismus a likvidace 'umění,'” 141. Emphases in original.

50. This is a paraphrase of a comment by Jaromír Krejcar; see Švácha, Architecture of New Prague, 270.

51. Teige, "Mundaneum," 91. Translation modified.

52. "Constructivism, abandoning obsolete aesthetic principles, returned to man as the

The Style of the Present: Karel Teige on Constructivism and Poetism 
measure of all things"; Teige, "K teorii konstruktivismu," 365. Statements like this only further demonstrate that interpreting the Mundaneum polemic in terms of Le Corbusier's "humanist" versus Teige's "utilitarian" positions runs against the problem that Teige was neither a utilitarian nor an antihumanist.

53. Le Corbusier, "In Defense of Architecture," 95.

54. Very few accounts in fact avoid interpreting Teige's dual program primarily through the lens of either Poetism or Constructivism. The best treatments of the program as striving for a dialectical unity are Vratislav Effenberger, Realita a poezie: K vývojové dialektice moderního uméni (Prague, 1969), esp. 187-222, as well as his concluding essays to each volume of $V z D$; Oleg Sus, "Totožnost člověka uprostřed víru," in Estetické problémy pod napětím, 35-47; and Květoslav Chvatík, Smysl moderního uměni (Prague, 1965), esp. 76-77, 80, and 87. Uffelmann's analysis ("Maximální funkčnost") is one of the most systematic attempts to trace logical consistency in the dualism through Teige's concept of function. The hazards of interpreting either of Teige's programs as primary and the other as subordinate are illustrated in Müller, Der Poetismus: shortly after describing Constructivism as the "notwendige Ergänzung des poetistischen Lebenstils" (33), Müller quotes a passage from "Poetism" in which Teige in fact describes Poetism as the complement to Constructivism (35).

55. See, e.g., Jaroslav Anděl's claim that "unlike other, better-known movements and organizations, which advanced one dominant principle (either rational or irrational), Devětsil . . . sought to achieve the improbable goal of wedding opposing artistic tendencies by capturing the polarities of the modern world and celebrating its beauty; this goal was expressed in the group's slogan: 'Constructivism/ Poetism" "; "The 1920's: The Improbable Wedding of Constructivism and Poetism," in El Arte de la vanguardia en Checoslovaquia, 1918-1938 (The art of the avant-garde in Czechoslovakia, 1918-1938) (Valencia, Spain, 1993), 21.

56. Teige, "Poetism," 68 (translation modified); "Poetismus," 123.

57. On the comparison to Karl Marx's base/superstructure image see Sus, Estetické problémy pod napétím, 40; Srp, "Teige in the Twenties," 28; and Uffelmann, "Maximální funkčnost," 397.

58. Teige, "Poetism," 68 (translation modified); "Poetismus," 123. Vítězslav Nezval defined Poetism as "a method of viewing the world so that it becomes a poem"; quoted in Květoslav Chvatík, Bedrich Václavek a vývoj české marxistické estetiky (Prague, 1962), 79.

59. See Teige, "Manifest poetismu," 323 and 326; partially translated in "Excerpts from 'Poetism Manifesto,", 593. 